\title{
Determinants of Consumer Happiness and Its Role in Customer Loyalty
}

\author{
SHAHZAD KHAN \\ Lecturer City University of Science and Information Technology Peshawar Pakistan \\ Email: Shahzadkhan.lecturer@gmail.com \\ Tel: +92-3339405596
}

MUNTAZIR HUSSAIN

PhD Research Scholar International Islamic University Islamabad Pakistan.

Email: muntazirjan@gmail.com

\begin{abstract}
Consumer happiness is the important area of research for marketers as happy consumer is the satisfied consumer of a company which generates significant revenue for the company. This research is conducted for the very same reason to find that what are the different factors which make consumer happy. Study identifies different determinants of consumer happiness and checks their influence on student's happiness. Study selected four private universities. The four universities were Preston University, Cecos University, Abasyn University and City University of Science and Information Technology Peshawar Pakistan. The data collected through a structured self administered questionnaire at 5 point lickert scale from 100 students of above mentioned universities. Study use SPSS 19 for the analysis purpose and conduct descriptive analysis, correlation and multiple regression for the findings. Findings of the study shows that Rationality, situation and culture are the prominent antecedents of consumer happiness which play major role in making consumer happy towards various brand of different firms.
\end{abstract}

Key Word: Consumer Happiness, Rational, Emotions, Customer Value, Customer relationship, Situation and Culture.

\section{Introduction}

All over the world various researches has conducted many work on customer loyalty and its impact on sale and profitability of the firm. But a question arise when a consumer become loyal? There is a variable that lies before the customer loyalty that is consumer happiness. Consumer happiness is the feeling of a consumer when a consumer expressing joy. Emerging trend of business is a good side for the economies. Increasing competition focus more on the aspect of customer retention through applying various marketing activities. Consumer happiness is one of the tool among those factors. This research is conducted for the reason to find that how consumer can be happier. What are the different factors which are responsible for making consumer happy and how these factors contribute towards consumer happiness. The time has changed when firms was only providing the product, price, place and promotion. The company are now emphasizing on even more. Today's firms need to understand the realistic and emotions of consumers, their culture and provide maximum customer value along with relationship marketing according to the situations. Consumers don't want to be "satisfied," they want to be happy. Your product's long-term success depends on loftier goals and a broader array of design strategies that deliver emotional and social results for your customers (Richard 1995). This research is focused on that what are the key antecedents of consumer happiness and which of them play most important and crucial role in consumer happiness in universities students of Peshawar Pakistan. Study has considered four universities i,e Preston University, Cecos University, Abasyn University and City University of Science and Information Technology Peshawar Pakistan. These universities students are targeted to find the role of Rational, Emotions, Customer Value, Customer relationship, Fate/Fight Situation and Culture on consumer happiness. 


\section{Literature Review}

Consumers don't want to be "satisfied" they want to be happy. And here's the rub: For all the millions of dollars spent on customer satisfaction initiatives, and for all the brand innovations companies have created over decades, consumers are no happier today than they were 50 years ago (Richard 2001). It is possible to go beyond more satisfaction to produce customer happiness. But to get the job done, companies need to bring to market solutions that actually increase both the feelings and the meaning that customers ascribe to being happy. When a company decides to commit itself to producing durable happiness, its innovations last longer, its brands deliver, and those brands create lasting loyalty. Research provide principles for designing brand experiences to facilitate increased happiness by focusing on the jobs to get done, the four customer "dispositions" toward happiness, and the key moments that have the greatest impact over a longer time period (Rutt 2002).

In study of Richard (2001) feeling happier is one of the great unmet challenges of modern consumption and it's this challenge that design thinking should be addressing, rather than focusing on methodologies for customer satisfaction. The steady rise in GNP levels over 50 years has not been accompanied by rises in national happiness levels despite millions of customer satisfaction survey questions and millions of dollars spent.

In study of Frey, Bruno and Stutzer (2002) to produce durable happiness, companies must have a long-term strategy to develop the emotional or social jobs their customers want done. When customers hire you to help them accomplish a task, you are doing a functional job. When they hire you to help them feel something, you're doing an emotional job. When they hire you to help them relate to others, you're doing a social job. The study of Roger (1999) aiming for customer satisfaction around a functional job can be expensive. Think about banks and credit unions. Before online banking, most people went to branch locations to accomplish things like transferring money to an account. Before ATMs, they went to branch locations to get cash. Financial institutions realized that many of the traditional, functional reasons for going to a branch location were being disrupted by new technologies. And for a while banks believed that branches would disappear. But they didn't. For emotional and social reasons, many of their customers insisted on a location near their homes even though many of their transactions could be handled online. This created a quandary for financial institutions. Should they keep the expensive brick-and-mortar branch locations or not? Most banks did, because of customer demand.

\section{Antecedents of Consumer Happiness}

\section{Rationality}

According to Mufti, Khan and Zaheer (2011) that rational factors are the realistic factors like price, quality, saving and services etc which can contribute toward the consumer motivation. Consumer motivation for happiness is dependent the rational factors related to the product. The consumer happiness is dependent upon the rational factors for the reason that obtains the product of their choice with real aspect of the product or services.

\section{Emotions}

In study of Mufti, Khan and Zaheer (2011) they describe in their study that the word emotion has been derived from the French word 'emouvoir' that means "to move or to touch". Main focus of his research is pivoted around human emotions and its affective state of consciousness in which joy, sorrow, fear, love, feelings for children, and concerns about family are experienced. Consumer happiness has a direct relation with the emotions. Good or bad emotions can make consumer happy or sad depending upon situation. 


\section{Customer Value}

Kotler and Keller (2009) describe that customer value is the diffidence between benefits a customer gain and the cost a consumer pay in order to get a particular product.

They classify that there are four types of cost and four types of benefits that a consumer has better value. According to Mufti, Khan and Zaheer (2011) brand equity of the firm is also affected if the clear differentiation is not made between two brands of the company.

The four benefits are Product, service, image and personal benefits. While the four cost are price the monetary cost, time, energy and psychic cost also known the non monetary cost of a firm. The customer value has a significant impact on consumer happiness if benefited with extra superior benefits for a lowest cost will lead a greater happiness (Rust \& Zahorik 1993). Customer value is important for the reason that consumers are realistic and seek more rational aspects of the product. It is the firm ability that up to which level they understand consumers and make them happy upon providing value to them and can lead satisfied customers (Kotler and Keller 2009).

\section{Relationship Marketing}

The study of Shaker, Ismail and Alsadi (2010) describe that relationship is the social process in which people interact with each other. This interaction based on different aspects of life. The interaction may be bases on blood, social pressure, feelings or emotion or due to rational factors. Companies use relationship marketing as a tool for the reason to retain customers for longer time (Lin \& Wu 2011). The societal marketing concept and customer relationship marketing is develop for the reason to establish good relations with the consumers (Hauser, Simester \& Wernerfelt 1994). According to Kotler and Keller (2009) customer relationship marketing is the process of attracting, building and retaining customers. Good relation play important role in happiness. Consumer happiness is strongly dependent relationship marketing (Cherrier and Munoz (2007).

\section{Situation}

Happiness of a person depends upon situation. Each and every situation brings new circumstances with itself Vesel and Zabkar (2009). Each and every situation has its own characteristics in itself and those factors can make persons happy or sad depending the influence of that situation (Donald 1998).

\section{Culture}

Culture is the combination of beliefs, values and customs. Offering a product according to the culture of consumers can make happy consumers. The study of (Crotts and Erdmann 2000) represents that culture is one the most important factor in consumer dealing. Culture also include language, tastes patrons of living etc. culture become even more crucial in international trade for the consumer happiness (Kogut and Singh 1988).

\section{Hypothesis of the study}

On the basis of theoretical framework of the study following six hypotheses has been developed. Table 1 below show hypothesis of the study.

\begin{tabular}{|l|l|}
\hline Objectives & Table 1 Hypothesis of the Study. \\
\hline Antecedents of & H:1 There is a positive relationship between rationality and consumer happiness. \\
consumer happiness & H:2 Emotions has a positive impact on customer happiness. \\
and its relation. & H:3 There is a positive relationship between customer value and consumer happiness. \\
& H:4 Customer relationship has an impact on customer happiness. \\
& H:5 There is a positive relationship between situation and consumer happiness. \\
& H:6 Culture has positive impact on consumer happiness. \\
& \\
\hline
\end{tabular}


The study represent that customer satisfaction is dependent upon eight independent antecedents of relationship marketing. In other words customer satisfaction is dependent upon antecedents of relationship marketing.

\section{Theoretical Framework of the Study}

Research consists of the following research framework. Research has dependent variable in shape of consumer happiness. While there are six independent variables of this study.

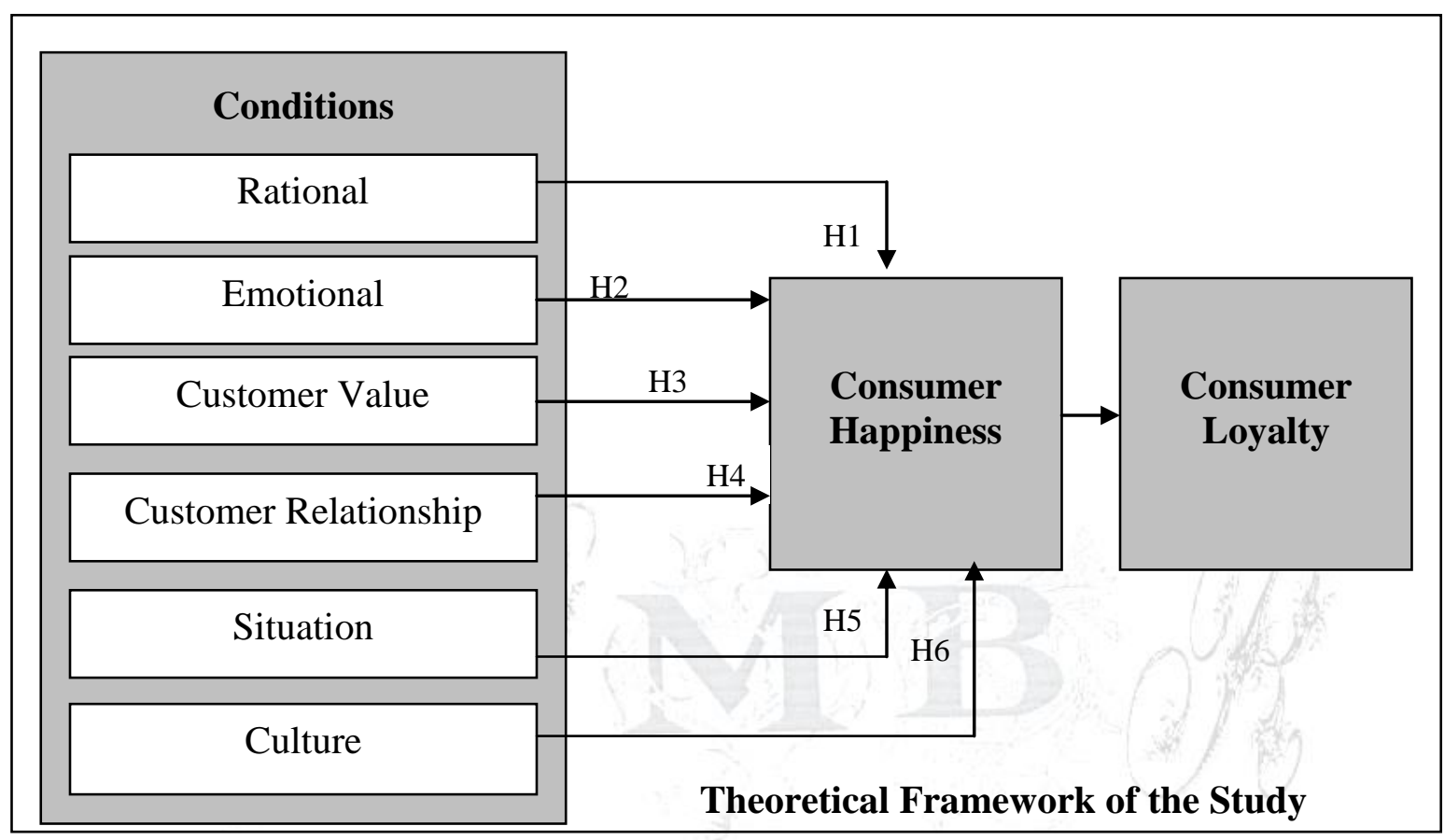

The six independent variables are Rational, Emotions, Customer Value, Customer relationship, Fate/Fight Situation and Culture. Consumer becomes loyal if the feel happy.

\section{Research Methodology}

\section{Data collection}

For research both primary and secondary data were collected. The methods used for collecting primary and secondary data are as follows:

The method used to collect Primary data includes a structured self administered 5 point lickert scale questionnaire, from university students of Peshawar Pakistan. Methods used to collect secondary data, include, research papers, circular, newsletters, journals and internet.

\section{Sample size and Statistical Tool}

The respondents of the study were the university students of Peshawar Pakistan. Four different universities student were targeted fro the purpose on convenient basis. These universities were Preston University, Cecos University, Abasyn University and City University of Science and Information Technology Peshawar Pakistan. The data collected through questionnaire from students of above mentioned universities. The study use probability sampling for primary data collection. A random sampling method used for the sample selection of 100 students. For the analysis purpose of the study Correlation and 
multiple linear regression used to find the significance between consumer happiness and its antecedents which are the independent factors of the study.

\section{Socio-Demographic Profile}

Table 2 below shows the demographical analysis of 100 respondents. Descriptive table below shows that $74 \%$ of the respondents are male and $26 \%$ respondents are female. Table 1 also explained that $9 \%$ respondents were in the age group of $18-19$, while in age ranged from $20-21,21 \%$ of respondents. While in age of $22-23$ only $26 \%$ respondents and respondents having age more than 24 are only $44 \%$. The response of the study shows that $17 \%$ family income is above 10000 and below 20000, while in family income of above 20000 and below 30000 is $47 \%$.

Table 2: Demographical Result

\begin{tabular}{|c|c|c|c|}
\hline Measures & Items & Frequency & Percentage \\
\hline Gender & Male & 74 & $74 \%$ \\
& Female & 26 & $26 \%$ \\
\hline Age & $18-19$ & 9 & $9 \%$ \\
& $20-21$ & 21 & $21 \%$ \\
& $22-23$ & 26 & $26 \%$ \\
& $\geq 24$ & 44 & $44 \%$ \\
\hline Family Income & $>10000<20000$ & 17 & $17 \%$ \\
& $>20000<30000$ & 47 & $47 \%$ \\
& $>30000<40000$ & 25 & $25 \%$ \\
& $>40000<50000$ & 7 & $7 \%$ \\
& $>50000$ & 4 & $4 \%$ \\
\hline
\end{tabular}

There are $25 \%$ respondents who has the family income of above 30000 and below 40000 while $7 \%$ respondents lies in income group of above 40000 and below 50000 while only $4 \%$ has income above 50000 .

\section{Results and Analysis}

For analysis part of the study statistical package for social science 19 were used. The study use descriptive analysis, correlation and regression analysis to find the impact of Rational, Emotions, Customer Value, Customer relationship, Fate/Fight Situation and Culture on consumer happiness.

\section{Table 3: Descriptive Analysis}

\begin{tabular}{|c|c|c|c|c|}
\hline \multicolumn{5}{|c|}{ Descriptive Statistics } \\
\hline & $\mathbf{N}$ & Mean & $\begin{array}{c}\text { Std. } \\
\text { Deviation }\end{array}$ & \begin{tabular}{|c|} 
Cronbach's \\
Alpha \\
\end{tabular} \\
\hline Consumer Happiness 1 & 100 & 3.6694 & .82365 & \multirow{4}{*}{0.831} \\
\hline Consumer Happiness 2 & 100 & 3.2984 & .96255 & \\
\hline Consumer Happiness 3 & 100 & 3.3065 & .91222 & \\
\hline Consumer Happiness 4 & 100 & 3.4274 & .88505 & \\
\hline Rational 1 & 100 & 3.6452 & 1.03746 & \multirow[b]{3}{*}{0.824} \\
\hline Rational 2 & 100 & 3.1935 & 1.06441 & \\
\hline Rational 3 & 100 & 3.3226 & .96734 & \\
\hline
\end{tabular}




\begin{tabular}{|c|c|c|c|c|}
\hline Emotions 1 & 100 & 3.8468 & .62527 & \multirow{4}{*}{0.701} \\
\hline Emotions 2 & 100 & 3.5806 & .90254 & \\
\hline Emotions 3 & 100 & 3.8790 & .79216 & \\
\hline Emotions 4 & 100 & 3.7823 & .91563 & \\
\hline Customer Value 1 & 100 & 3.8710 & 1.04351 & \multirow{4}{*}{0.819} \\
\hline Customer Value 2 & 100 & 3.2903 & 1.08781 & \\
\hline Customer Value 3 & 100 & 3.3226 & .96734 & \\
\hline Customer Value 4 & 100 & 3.4839 & .98347 & \\
\hline Customer Relationship 1 & 100 & 3.6129 & .90805 & \multirow{4}{*}{0.890} \\
\hline Customer Relationship 2 & 100 & 3.2581 & 1.05052 & \\
\hline Customer Relationship 3 & 100 & 3.3548 & .93872 & \\
\hline Customer Relationship 4 & 100 & 3.3871 & 1.00979 & \\
\hline Situation 1 & 100 & 3.5161 & .94983 & \multirow{4}{*}{0.856} \\
\hline Situation 2 & 100 & 3.1935 & 1.06441 & \\
\hline Situation 3 & 100 & 3.3226 & .96734 & \\
\hline Situation 4 & 100 & 3.3548 & 1.03746 & \\
\hline Culture 1 & 100 & 3.6452 & .82830 & \multirow{4}{*}{0.881} \\
\hline Culture 2 & 100 & 3.1935 & 1.06441 & \\
\hline Culture 3 & 100 & 3.3871 & .94318 & \\
\hline Culture 4 & 100 & 3.5161 & .91495 & \\
\hline Valid N (listwise) & 100 & & & \\
\hline
\end{tabular}

\section{Regression Results}

The following results were obtained after fitting the multiple linear regressions.

Table IV: Model summary.

\begin{tabular}{|l|c|r|r|r|}
\hline Table 4 & \multicolumn{4}{|c|}{ Model Summary } \\
\hline Model & $\mathbf{R}$ & $\mathbf{R}$ Square & $\begin{array}{c}\text { Adjusted R } \\
\text { Square }\end{array}$ & Std. Error of the Estimate \\
\hline 1 & .883 & .746 & .779 & .25738 \\
\hline $\begin{array}{l}\text { a. Predictors: (Constant), Rational, Emotions, Customer Value, Customer relationship, } \\
\text { Situation and Culture. }\end{array}$
\end{tabular}

The adjusted R-square in the table 2 shows that the dependent variable, (Consumer Happiness) is affected $77.9 \%$ by independent variables (Rational, Emotions, Customer Value, Customer relationship, Fate/Fight Situation and Culture.). It shows that mentioned independent variables are responsible for consumer Happiness. The overall model was also significant, tested with the help of ANOVA. The results are given in the following table 3 . 
Table V: ANOVA Results.

\begin{tabular}{|c|c|c|c|c|c|c|}
\hline \multirow{2}{*}{\multicolumn{2}{|c|}{$\begin{array}{l}\text { Table } 5 \\
\text { Model }\end{array}$}} & \multicolumn{5}{|c|}{ ANOVA $^{a}$} \\
\hline & & Sum of Squares & Df & Mean Square & $\mathbf{F}$ & Sig. \\
\hline \multirow{3}{*}{1} & Regression & 7.643 & 7 & 3.254 & 21.354 & $.000^{\mathrm{b}}$ \\
\hline & Residual & 5.36 & 93 & .056 & & \\
\hline & Total & 13.003 & 100 & & & \\
\hline \multicolumn{7}{|c|}{ a. Dependent Variable: Consumer Happiness } \\
\hline
\end{tabular}

ANOVA table is showing the level of significance. Through the table it is clear that all independents factors Rational, Emotions, Customer Value, Customer relationship, Fate/Fight Situation and Culture are related to consumer happiness and that the relationship between them is significant as compared to alpha value $=0.05$. Table VI shows the coefficients of all independent variables included in the model along with their respective P-values.

Table VI: Regression Co-efficient

All the antecedents of consumer happiness are significant. In the table 6 below, un-standardized coefficient shows that the all factors are positively affecting the consumer happiness.

\begin{tabular}{|c|c|c|c|c|c|c|}
\hline \multirow{3}{*}{\multicolumn{2}{|c|}{$\frac{\text { Table } 6}{\text { Model }}$}} & \multicolumn{5}{|c|}{ Coefficients $^{a}$} \\
\hline & & \multicolumn{2}{|c|}{$\begin{array}{c}\text { Unstandardized } \\
\text { Coefficients } \\
\end{array}$} & \multirow{2}{*}{$\begin{array}{c}\text { Standardized } \\
\text { Coefficients } \\
\text { Beta }\end{array}$} & \multirow[t]{2}{*}{$\mathbf{T}$} & \multirow[t]{2}{*}{ Sig. } \\
\hline & & B & Std. Error & & & \\
\hline \multirow{7}{*}{1} & (Constant) & 2.648 & .256 & & 3.657 & .000 \\
\hline & Rational & .148 & .069 & .473 & 1.578 & .000 \\
\hline & Emotional & .294 & .044 & .236 & 2.456 & .000 \\
\hline & Customer Value & .141 & .061 & .226 & 1.256 & .000 \\
\hline & $\begin{array}{l}\text { Customer } \\
\text { Relationship }\end{array}$ & .269 & .017 & .214 & 2.567 & .000 \\
\hline & Situation & .156 & .054 & .424 & 3.487 & .000 \\
\hline & Culture & .175 & .085 & .267 & 2.879 & .000 \\
\hline
\end{tabular}

As it clear from the table 6 above that each and every factor is significantly related to 'Consumer happiness'. Under the standardized coefficients it is evident that: 'Rational and situation' are the two majors and most important antecedents of consumer happiness which make consumer happy and consumer happiness leads to customer satisfaction that lead loyalty. Study shows that rationality with a standardize coefficient of $(b=0.473)$ in order of importance second important variable is 'situation' with a standardize coefficient of $(\mathrm{b}=0.424)$. 
The third important variable is 'culture' with a standardize coefficient of $(b=0.267)$. Hence there are three main factors that are responsible in order for consumer happiness in university students of Peshawar Pakistan. Other factors of the study has weak impact on consumer happiness as compare to above mentioned factors like 'Emotions' ( $b=0.236)$, 'Customer Value' $(b=0.226)$, 'Customer relationship' $(b=$ 0.214 ). As the table shows positive values and all factors are significant at value $=0.05$ it is concluded that the entire list of hypothesis is endorsed.

\section{Findings and Conclusion}

This research wad conducted to find that what are the key elements of consumer happiness and how these factors can influence consumer happiness. For the purpose the universities students of Peshawar Pakistan were taken as unit of analysis. Study results show that all factors have significant impact on consumer happiness. The study identified three major factors which has greater impact on consumer happiness. These three factors are Rationality, situation and Culture. Study findings say that all factors have positive influence on students happiness but these three factors have more contribution as compared to others variables. But according to findings rationality is the most important factor that leads or contribute more towards consumer happiness with a standardize coefficient of $(b=0.473)$. The second important factor is 'situation' with a standardize coefficient of $(b=0.424)$. While the third important variable is 'culture' with a standardize coefficient of $(b=0.267)$. Hence this study suggests that it is important for consumer happiness to provide them rationality according to the situation and their culture.

\section{References}

Crotts, J., and R. Erdmann (2000). “Does National Culture Influence Consumers' Evaluations of Travel Services? A Test of Hofstede's Model of Cross-Cultural Differences." Managing Service Quality, 10 (6): 410-19.

Easterlin, Richard A. (1995), "Will Raising Income of All Increase the Happiness of All," Journal of Economic Behavior \& Organization, 27 (1), 35-47.

Easterlin, Richard A. (2001), "Income and Happiness: Towards a Unified Theory," The Economic Journal, 111 (473), 465-484.

Frey, Bruno S. and Alois Stutzer (2002), "What Can Economists Learn from Happiness Research" Journal of Economic Literature, 40 (2), 402-435.

Hauser, J. R., Simester, D. I., \& Wernerfelt, B. (1994) “Customer satisfaction incentives". Marketing Science, 13(4), 327-350.

Helene Cherrier and Caroline Lego Munoz (2007) “A Reflection on Consumers' Happiness: The Relevance of Care for Others, Spiritual Reflection, and Financial Detachment" Journal for consumer research. Issue 12 pp 1-19

Kogut, B., and H. Singh (1988). "The Effect of National Culture on the Choice of Entry Mode." Journal of International Business Studies, 19 (3): 411-32.

Kotler, P. and Keller, K.L. (2009) Marketing Management. Pearson International Edition. 13th Edition. Pearson Education Inc. Upper-saddle River.

Lehmann, Donald R. (1998). "Customer reactions to variety: too much of a good thing?" Journal of the Academy of Marketing Science 26 (1): 62-65. 
Lin, J. S. C., \& Wu, C. Y., (2011) "The role of expected future use in relationship-based service retention". Managing Service Quality, 21(5), 535-551.

Owais Mufti, Shahzad khan, Zafar Zaheer (2011) "Impact of Rational and Emotional Factors in Creating Consumer Motivation, a Study of Policy Holders of State Life Insurance Corporation in KPK, Pakistan" European journal of social sciences. Volume 24, Number IV pp 546-552.

Rosenblatt, Roger (1999), Consuming Desires: Consumption, Culture, and the Pursuit of Happiness, Washington, D.C. Island Press.

Rust, R. T., \& Zahorik, A. J. (1993) "Customer Satisfaction, Customer Retention and Market Share". Journal of retailing, 69 (2), 193-215.

Shaker, T. Ismail and Basem, Y. Alsadi (2010) "Relationship Marketing and Organizational Performance Indicators" European Journal of Social Sciences. Volume 12, Number 4 pp545-557

Veenhoven, Rutt (2002), World Database of Happiness. Continuous Register of Research on Subjective Enjoyment of Life, Accessed online: www.eur.nl/fsw/research/happiness.

Vesel, P., \& Zabkar, V. (2009) "Managing customer loyalty through the mediating role of satisfaction in the DIY retail loyalty program". Journal of retailing and customer services, 16, 396-406. 